\title{
Biocompatibility of Human Auricular Chondrocytes Cultured onto a Chitosan/Polyvynil Alcohol/Epichlorohydrin-Based Hydrogel for Tissue Engineering Application
}

\author{
Biocompatibilidad de Condrocitos Humanos Cultivados Sobre un Hidrogel a Base de \\ Quitosano/Alcohol Polivnílico/Epiclorhidrina para Aplicación en Ingeniería de Tejidos
}

\begin{abstract}
Yaaziel Melgarejo-Ramírez; Roberto Sánchez-Sánchez*; Zaira García-Carvajal*; Julieta García-López; Claudia GutiérrezGómez $^{* *}$; Gabriel Luna-Barcenas ${ }^{* * *}$; Clemente Ibarra* \& Cristina Velasquillo*
\end{abstract}

MELGAREJO-RAMÍREZ, Y.; SÁNCHEZ-SÁNCHEZ, R.; GARCÍA-CARVAJAL, Z.; GARCÍA-LÓPEZ, J.; GUTIÉRREZGÓMEZ, C.; LUNA-BARCENAS, G.; IBARRA, C. \& VELASQUILLO, C. Biocompatibility of human auricular chondrocytes cultured onto a chitosan/polyvynil alcohol/epichlorohydrin-based hydrogel for tissue engineering application. Int. J. Morphol., 32(4):1347$1356,2014$.

SUMMARY: Tissue engineering (TE) has become an alternative for auricular reconstruction based on the combination of cells, molecular signals and biomaterials. Scaffolds are biomaterials that provide structural support for cell attachment and subsequent tissue development. Ideally, a scaffold should have characteristics such as biocompatibility and bioactivity to adequate support cell functions. Our purpose was to evaluate biocompatibility of microtic auricular chondrocytes seeded onto a chitosan-polyvinyl alcohol-epichlorohydrin (CS-PVA-ECH) hydrogel to propose this material as a scaffold for tissue engineering application. After being cultured onto CS-PVAECH hydrogels, auricular chondrocytes viability was up to $81 \%$. SEM analysis showed cell attachment and extracellular matrix formation that was confirmed by IF detection of type II collagen and elastin, the main constituents of elastic cartilage. Expression of elastic cartilage molecular markers during in vitro expansion and during culture onto hydrogels allowed confirming auricular chondrocyte phenotype. In vivo assay of tissue formation revealed generation of neotissues with similar physical characteristics and protein composition to those found in elastic cartilage. According to our results, biocompatibility of the CS-PVA-ECH hydrogel makes it a suitable scaffold for tissue engineering application aimed to elastic cartilage regeneration.

KEY WORDS: Elastic cartilage; Auricular reconstruction; Chitosan hydrogel; Tissue engineering; Biocompatibility.

\section{INTRODUCTION}

Tissue engineering (TE) focused on elastic cartilage regeneration has become the alternative to perform auricular reconstruction for the treatment of microtia and other injuries associated with absence or loss of auricular tissue (e.g., traumatism or burns) (Luquetti et al., 2012). One of the strategies of tissue engineering (TE) is the use of autologous tissue as a source of cells and the combination with different biomaterials in order to promote the generation of a tissue with the same characteristics as the original. The use of autologous cells avoids future rejection reactions when engineered tissues are grafted into the host body (Kobayashi et al., 2011). Auricular chondrocytes constitute elastic cartilage; they lie isolated within the extracellular matrix (ECM) in a low oxygen tension environment (Ruszymah et al., 2007), they secrete elastin fibers along with type II collagen, aggrecan, proteoglycans, carbohydrates and interstitial fluid (Lafont et al., 2008). Biomaterials used as scaffolds are typically made of polymeric molecules to provide structural support for cell attachment and subsequent tissue development. They must interact with cellular components providing biological cues like cell-adhesive ligands to enhance attachment or physical cues such as topography to influence cell morphology and alignment (Nabzdyk, 2009). Ideally, a scaffold should have characteristics such as biocompatibility and bioactivity to promote cell attachment and growth; biodegradability; they also have to fullfill the mechanical properties to match those of the tissues at the site of implantation (Akiyama et al.,

\footnotetext{
Laboratorio de Biotecnología, Instituto Nacional de Rehabilitación, México D. F., México.

** División de Cirugía Plástica y Reconstructiva. Hospital General Dr. Manuel Gea González. México D. F., México.

*** Laboratorio de Biopolímeros. Centro de Investigación y de Estudios Avanzados - IPN. Querétaro, México.

Support for this research was provided through CONACYT grants (Sectoriales 114359 and 78798).
} 
MELGAREJO-RAMÍREZ,Y; SÁNCHEZ-SÁNCHEZ, R; GARCÍA-CARVAJAL, Z; GARCÍA-LÓPEZ, J.; GUTIÉRREZ-GÓMEZ, C.; LUNA-BARCENAS, G.; IBARRA, C. \& VELASQUILLO, C. Biocompatibility of human auricular chondrocytes cultured onto a chitosan/polyvynil alcohol/epichlorohydrin-based hydrogel for tissue engineering application. Int. J. Morphol., 32(4):1347-1356, 2014.

2002). For the adequate production of a scaffold it is important to know the biology of the tissue that we pretend to regenerate and to demonstrate complete biocompatibility (Lee \& Shin, 2007). Natural and synthetic materials have been widely used as scaffolds for TE applications aimed at cartilage regeneration (Hutmacher et al., 2001). Chitosan (CS) is a natural biocompatible polymer, non-toxic, formed through the $\mathrm{N}$-deacetylation of chitin. It consists primarily of repeating units of $b$-1, 4-glucosamine and $\mathrm{N}$-acetylglucosamine, structurally similar to glycosaminoglycan (GAG) chains present in cartilage. Properties of chitosan scaffolds vary with molecular weight, crystallinity, affinity for water, deacetylation percentage and the related amino group content; making it widely used by researchers as an important and promising biomaterial (Vinatier et al., 2009; Gao et al., 2012; DiMartino et al., 2005). On the other hand, polyvinyl alcohol (PVA) is a synthetic, non-toxic, hydrophilic and biocompatible material used for different tissue engineering applications (Zhang \& Zhang, 2001; Dorj et al., 2012). Several methods have been used to modify natural chitosan either physically or chemically in order to improve its adsorption capacity. Crosslinking with epichlorohydrin $(\mathrm{ECH})$ can be cited as an example of the chitosan chemical modifications carried out in order to prevent its dissolution in acidic solutions. Crosslinking CS-PVA with ECH brings more construction stability through formation of a polymeric tridimensional network increasing its lifespan (Garnica-Palafox et al., 2014). The aim of our study was to evaluate the biocompatibility of human microtic auricular chondrocytes with a CS-PVA$\mathrm{ECH}$ based hydrogel in order to propose this material as a scaffold to support and promote neotissue formation. We demonstrate that chondrocytes isolated from microtic tissue and cultured onto CS-PVA-ECH hydrogel are able to survive after 20 days. Scanning electron microscopy (SEM) allowed visualizing cell attachment to the scaffold surface and ECM deposition. Cartilage molecular markers expression persisted during the in vitro expansion phase and after 20 days cultured onto CS-PVA-ECH scaffold confirming phenotype maintenance. The presence of ECM proteins was determined by immunohistochemistry. After implantation in an animal model, neotissue generated possessed a composition similar to that of the auricular cartilage. Our results suggest that the CS-PVA-ECH hydrogel could be used as a potential scaffold for ear reconstruction using TE techniques.

\section{MATERIAL AND METHOD}

All subjects enrolled in this research have responded to an Informed Consent wich has been approved by Institutional Committee on Human Research. All animals were treated in accordance with Public Health Service Policy on Humane Care and Use of Laboratory Animals (August 2002), implemented by the Office of Laboratory Animal Welfare, Harvard Medical School IACUC.

Synthesis of CS-PVA-ECH based hydrogel for human auricular chondrocytes culture. CS $2.5 \mathrm{~g}, 350,000 \mathrm{Da}$ with $85 \%$ of deacetylation degree (Sigma-Aldrich, St. Louis, MO) were dissolved in $100 \mathrm{~mL}$ of diluted acetic acid $(2.5 \% \mathrm{w} / \mathrm{w}$, 0.4 M, Darmstadt, Germany), 7.8 g of PVA, 89,000 Da and 99\% hydrolysis (Fluka/Aldrich Chemical, USA) were dissolved in $100 \mathrm{~mL}$ of distilled water at $80^{\circ} \mathrm{C}$. The two solutions were mixed at 2:1.5 ratio and poured onto a flask in a water bath with a magnetic stirrer at $40 \pm 2^{\circ} \mathrm{C}$ under nitrogen atmosphere. A NaOH solution (1 M, $1.0 \mathrm{~mL})$ was immediately added drop wise; ECH (0.25 mL, $99 \%$ SigmaAldrich, St. Louis, MO) was also added drop wise. The mixture was allowed to react for $1 \mathrm{~h}$ at $40 \pm 2^{\circ} \mathrm{C}$ and then allowed to cool down for $1 \mathrm{~h}$ in a nitrogen atmosphere. Five grams of the CS-PVA-ECH copolymer solution were poured onto a plastic Petri dish and dried at $37^{\circ} \mathrm{C}$ for $72 \mathrm{~h}$. Films were detached and washed three times with culture media before use for cell culture.

Characterization of CS-PVA-ECH based hydrogel using Fourier Transform Infrared Spectroscopy (FTIR). FTIR spectroscopy analysis (Spectrum GX, Perkin-Elmer, USA) were performed on dry CS-PVA-ECH films using the Attenuated Total Reflectance (ATR) technique. Spectra were recorded from $4000-400 \mathrm{~cm}^{-1}$ acquiring 16 scans with $2 \mathrm{~cm}-$ ${ }^{1}$ resolution per each spectrum.

Isolation and in vitro expansion of human auricular chondrocytes. Auricular cartilage remnants were obtained from five pediatric patients with microtia that were subjected to ear reconstruction procedures after informed patient consent. Ages of the patients ranged from six to nine years old and were previously diagnosed with unilateral microtia. Tissue was transported to the laboratory where it was mechanically disaggregated and pre-digested with $0.25 \%$ trypsin-EDTA (Gibco). Enzimatic digestion was performed at $37^{\circ} \mathrm{C}$ in Dulbecco's modified Eagle Medium and Ham's F12 medium (DMEM/F12; Gibco) containing 3 mg/mL type I collagenase (Worthington Biochemical Corporation). Isolated chondrocytes were filtered through a $100 \mathrm{~mm}$ nylon mesh (BD Falcon) and seeded in tissue culture flasks (BD Falcon) at $1.0 \times 10^{4}$ cells $/ \mathrm{cm}^{2}$ with DMEM-F12 medium supplemented with $10 \%$ Fetal bovine serum (FBS; Gibco) and $1 \%$ antibiotic-antimycotic solution (Gibco) in $5 \% \mathrm{CO}_{2}$ at $37^{\circ} \mathrm{C}$. All cells were maintained separately as individual samples throughout cell culture and for subsequent assays.

Scaffold-human auricular chondrocytes construct. After the CS-PVA-ECH copolymer was synthesized the solution 
MELGAREJO-RAMÍREZ, Y; SÁNCHEZ-SÁNCHEZ, R.; GARCÍA-CARVAJAL, Z.; GARCÍA-LÓPEZ, J.; GUTIÉRREZ-GÓMEZ, C.; LUNA-BARCENAS, G.; IBARRA, C. \& VELASQUILLO, C. Biocompatibility of human auricular chondrocytes cultured onto a chitosan/polyvynil alcohol/epichlorohydrin-based hydrogel for tissue engineering application. Int. J. Morphol., 32(4):1347-1356, 2014

was placed into a Petri dish for film formation and allowed to dry for $72 \mathrm{~h}$. Once the scaffolds were dried, they were physically cross-linked and sterilized for 30 min using UV radiation. Constructs were formed by seeding $3.0 \times 10^{5}$ chondrocytes $/ \mathrm{cm}^{2}$ from first passage (P1) onto $1.5 \mathrm{~cm}$ diameter circular-shaped hydrogels and kept in standard culture conditions. After 20 days culture, constructs were fixed for immunohistochemical analysis, viability assays or they were subcutaneously implanted in $\mathrm{Nu} / \mathrm{Nu}$ athymic mice during 4 months to allow neo-tissue formation. Mice were ethically sacrificed and neo-tissues were fixed for analysis.

Analysis of auricular chondrocytes viability. Viability of chondrocytes cultured onto hydrogels was evaluated using a Live/Dead viability/cytotoxicity kit for mammalian cells (Molecular probes, Invitrogen). After 20 days culture and previous subcutaneous implantation, constructs were washed and incubated with $1 \mu \mathrm{M}$ Calcein $\mathrm{AM}$ and $2 \mu \mathrm{M}$ Ethidium homodimer (EthD-1). Calcein fluorescent signal was observed using a Fluorescein band pass filter and EthD-1 with a Texas red filter. Images were acquired and analyzed using an Axiovision Observer A.1 microscope (Zeiss).

Determination of surface topography and elemental composition of auricular chondrocytes constructs. After 20 days culture, constructs were washed and fixed in a $2.5 \%$ glutaraldehyde/0.1 M PBS buffer ( $\mathrm{pH}=7.4)$. Constructs were placed over an aluminum holder, secured with carbon tape and analyzed with a Scanning Electron Microscope (SEM XL-30 Phillips Electronics, Holland) in a low vaccum environment. Energy-dispersive X-ray (EDX) spectrometry (EDAX-New XL-30, USA) was also performed. SEM working conditions were $25 \mathrm{kV}$, Spot 5, 10\% dead time, 200 sec live time, $10 \mathrm{~mm}$ working distance (WD), $2200 \mathrm{cpm}$ and 0.5 Torr.

Analysis of ECM proteins produced in auricular chondrocytes constructs. After 20 days culture, constructs were washed and fixed in a 1\% Paraformaldehyde/0.1 M PBS buffer $(\mathrm{pH}=7.4)$. Cells were immunolabeled with primary antibodies, mouse anti-human elastin monoclonal antibody (1:50, Santa Cruz) and mouse anti-human type I collagen monoclonal antibody (1:50, Santa Cruz) at $4^{\circ} \mathrm{C}$ overnight. Constructs were washed and incubated with respective biotinylated or Alexa Fluor-conjugated secondary antibodies for $1 \mathrm{~h}$ at room temperature. The chromogenic reaction to detect the antigen was performed using horseradish peroxidase and 3', 3'-Diaminobenzidine. Harris hematoxylin was used to counterstain chondrocytes nuclei. For immunofluorescence, nuclei were stained with $1 \mathrm{mg} /$ mL of 4', 6-diamidine-2-phenylidole-dihydrochloride (DAPI) for 10 minutes. Images were captured with an Axiovision Observer A.1 microscope (Zeiss).
Gene expression analysis of auricular chondrocytes. Total RNA from chondrocytes was isolated from tissue (T), primary culture (PC), first passage (P1) and after 20 days culture onto hydrogels (Sca) using TRIzol reagent (Invitrogen). Yield and purity was measured using a spectrophotometer (Nanodrop 2000c, Thermo). For reverse transcription-polymerase chain reaction (RT-PCR) a final concentration of $1 \mathrm{mg}$ RNA was adjusted for each sample. Expression of human SRY (sex determining region 1)-box 9 (SOX9; NM_000346.3), type II collagen (COL2A1; NM_1844.4/NM_033150.2), elastin (ELN; NM_000501.2/ NM_001081752.1), aggrecan (ACAN; NM_001135.3/ NM_013227.3)] and [collagen I (COL1A2; NM_000089.3)] molecular markers were analyzed by PCR. Reactions were carried out using a 2728 Thermal cycler (Applied Biosystems). PCR products were subjected to electrophoresis on a $1.2 \%$ agarose gel and visualized by ethidium bromide staining.

Statistical analysis. All experiments were independently repeated at least three times. Statistics were determined by means of Student's t-test (comparing two groups) using Graph-Pad Prism 5; p values <0.05 were considered to be statistically significant. Cell percentages were calculated counting individual cells in at least five fields per experiment, data was expressed as Mean \pm Standard Error of the Mean (MES).

\section{RESULTS}

CS-PVA-ECH based hydrogel maintained reported characteristics as determined by Fourier Transform Infrared Spectroscopy (FTIR-ATR). We previously reported the mechanical characterization of the CS-PVAECH based hydrogel. With this in mind, we considered relevant to corroborate the reproducibility of the hydrogel synthesis method for our studies. Figure 1 shows the FTIRATR spectra of pristine CS, PVA and CS-PVA, CS-PVA$\mathrm{ECH}$, and CS-PVA-ECH-UV (CS-PVA-ECH treated with UV radiation) blends showing their characteristic peaks as previously described (Nabzdyk, 2009).

Auricular chondrocytes derived from microtia patients are successfully expanded in vitro preserving morphological characteristics. An average of 3.5 x 106 cells/g were obtained from microtic tissue. Primary culture (PC) was established in order to increase cell number, wich originally started with a density of $1.0 \times 10^{4}$ cells $/ \mathrm{cm}^{2}$. By culture day two, most of the cells were firmly attached to the surface of the culture plate (Fig. 2A) and by day 15, chondrocytes were confluent and displayed characteristic 
MELGAREJO-RAMÍREZ, Y.; SÁNCHEZ-SÁNCHEZ, R.; GARCÍA-CARVAJAL, Z.; GARCÍA-LÓPEZ, J.; GUTIÉRREZ-GÓMEZ, C.; LUNA-BARCENAS, G.; IBARRA, C. \& VELASQUILLO, C. Biocompatibility of human auricular chondrocytes cultured onto a chitosan/polyvynil alcohol/epichlorohydrin-based hydrogel for tissue engineering application. Int. J. Morphol., 32(4):1347-1356, 2014

polygonal to spindle shape (Fig. 2B). Chondrocytes were tripsinized, first passage (P1) culture was generated and monolayer formation occurred after two weeks culture (Fig. 2B and $\mathrm{C})$. At the end of PC approximately $7.0 \times 10^{6}$ cells were obtained; the same number increased close to $21.0 \times 106$ cells once P1 finished. A threefold increase in the number of cells with no differences among samples was obtained (Data
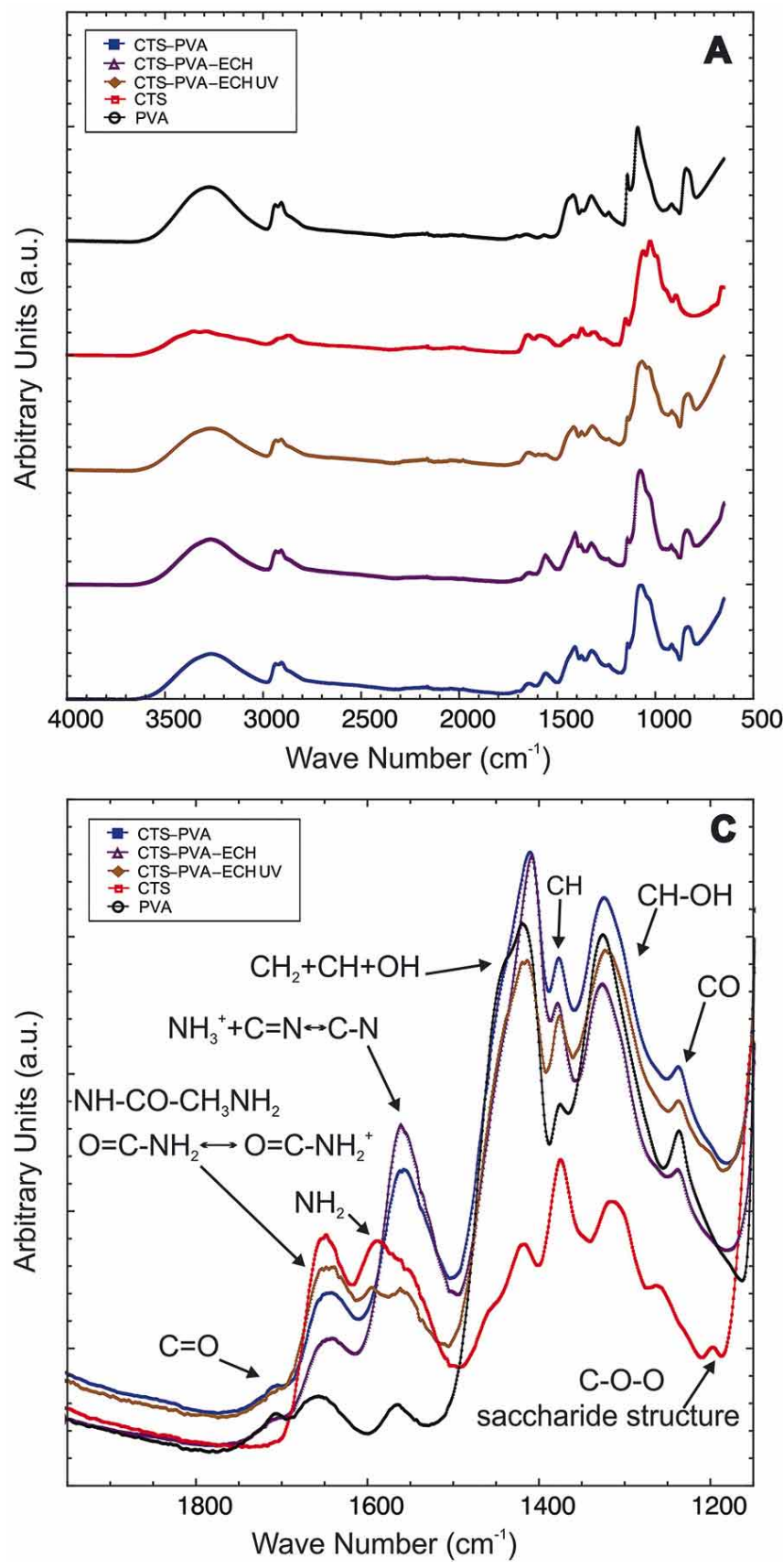

not shown). Even though chondrocytes were isolated from microtic tissue, their morphology and growth in culture conditions was similar to that observed in chondrocytes from normal elastic cartilage. This result confirms the convenience of using isolated microtic chondrocytes for tissue engineering applications. Once P1 cells were confluent they were trypsinized and seeded onto CS-PVA hydrogels.
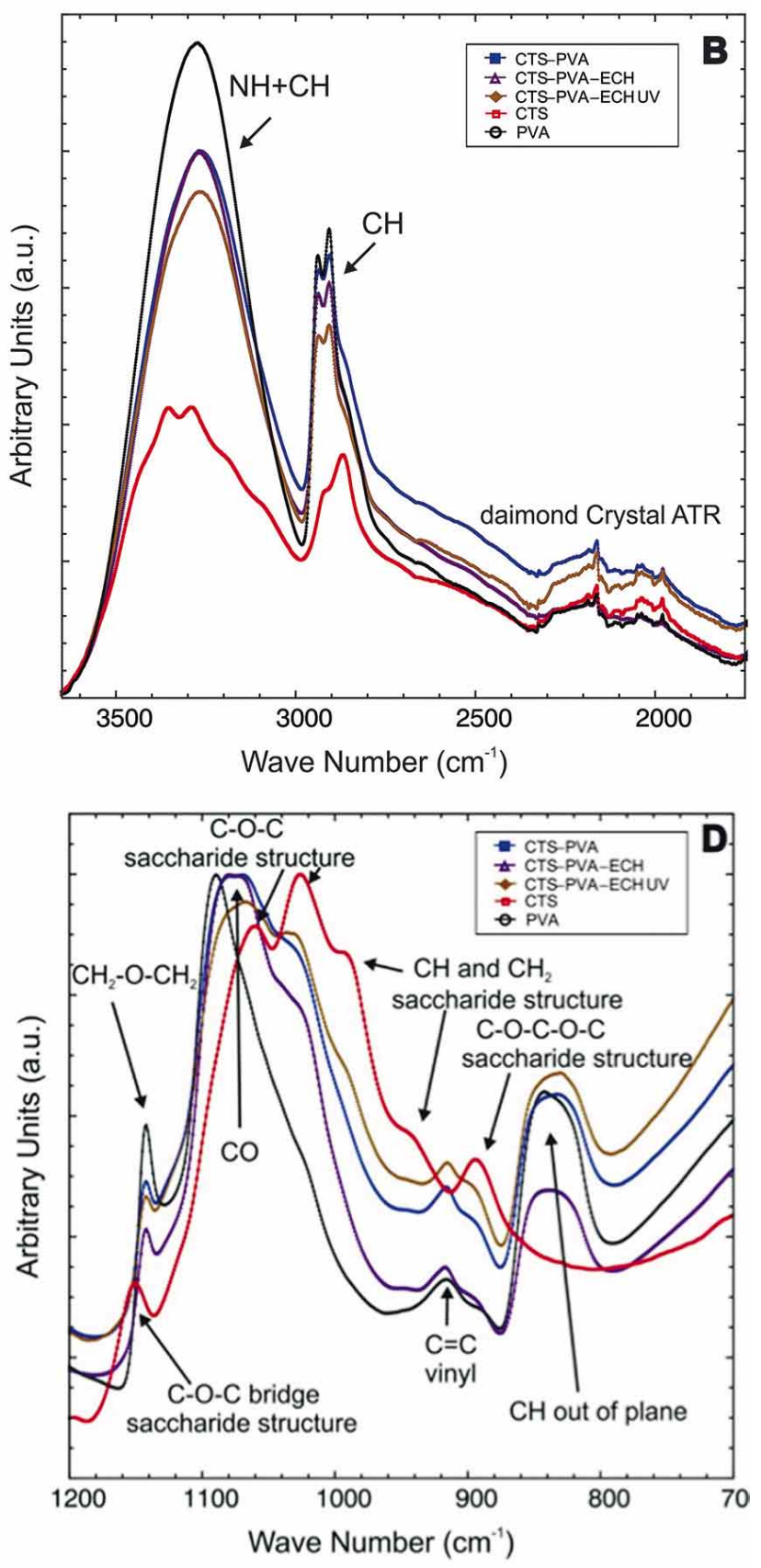

Fig. 1. Synthesis of CS-PVA-ECH based hydrogel maintained reported characteristics. ATR FTIR spectra of pristine PVA (black), Chitosan (red), CS-PVA blend (blue), CS-PVA-ECH blend (purple) and CS-PVA-ECH crosslinked with epichlorohydrin (yellow). Figure 2A shows the material's spectra in the 4000-700 cm-1 range; Figure 2B, 3500-2000 cm-1; Figure 2C, 1800-1200 cm-1; and Figure 2D, $1200-700 \mathrm{~cm}-1$. 


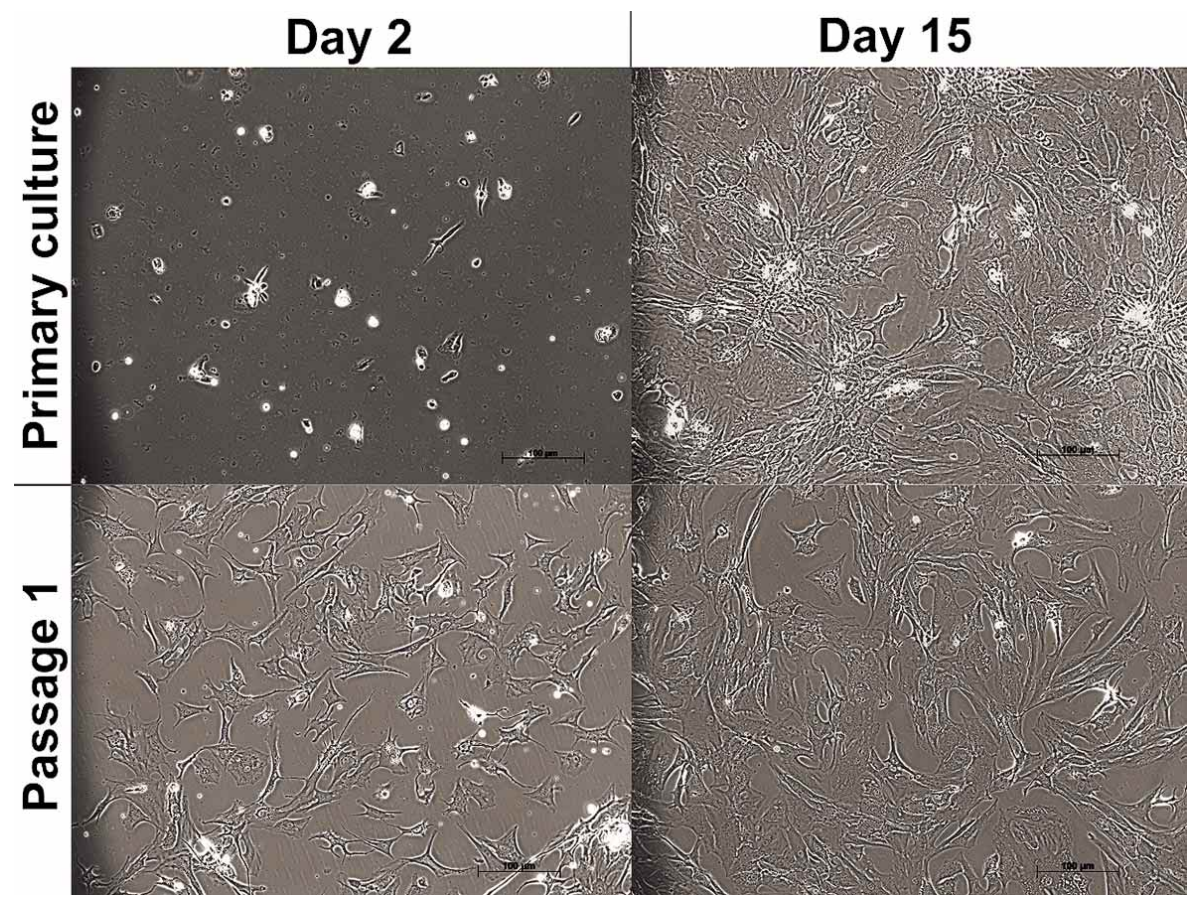

Fig. 2. Auricular chondrocytes from microtic tissue preserve morphological characteristics during in vitro expansion. Chondrocytes from microtic tissue displayed typical polygonal to spindle shape by day two and day 15 in primary culture $(\mathrm{PC})$. Bottom pictures show auricular chondrocytes during first passage (P1).

CS-PVA-ECH hydrogel allows auricular chondrocytes attachment, cell viability and production of elastic cartilage extracellular matrix. We now evaluated viability, cell attachment, molecular phenotype and extracellular matrix deposition of auricular chondrocytes cultured onto the CS-PVA-ECH hydrogel as a potential scaffold for tissue engineering. Calcein assay allows visualization of viable cells as a green signal. Percentage of viable cells in constructs is significantly higher (Mean \pm MSE $81.00 \pm 5.03 \%$ ) than dead cells (Mean \pm MSE $19.00 \pm 5.03 \%$ ) after 20 days culture (Fig. $3 \mathrm{~A}$ and $\mathrm{B}$ ) and prior implantation. As shown in Figure 3B, chondrocytes display characteristic polygonal morphology and grow up forming a monolayer that covers the hydrogel surface. Formation of ECM determines the physical properties of tissue and has an active role regulating cell survival, development, migration, proliferation, shape and function. Therefore, we were interested in evaluating cell attachment and secretion of cartilage ECM proteins. After 20 days culture and previous implantation, constructs were fixated and analyzed using scanning electron microscopy. SEM micrographs showed that the CS-PVA-ECH hydrogel presented few irregularities and a smooth surface; while

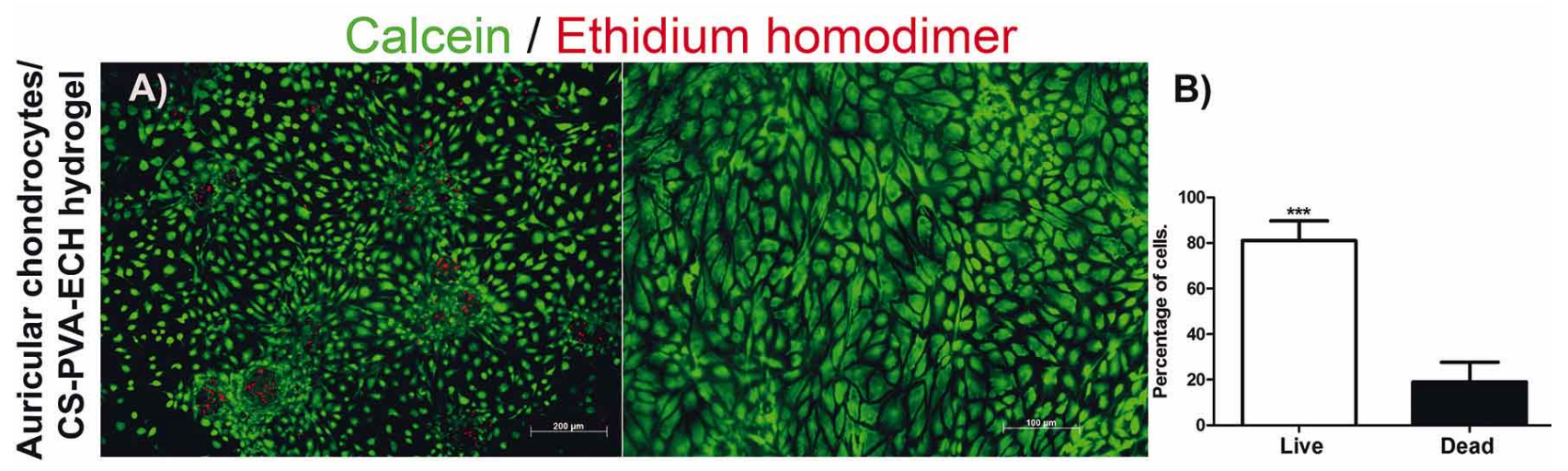

Fig. 3. Chondrocytes cultured onto CS-PVA-ECH hydrogel remain viable after 20 days culture. Analysis of cellular viability was performed using calcein (green) and ethidium homodimer (red) in chondrocytes grown onto CS-PVA-ECH hydrogels. Representative photographs were taken at different magnification (A). The graph shows percentage of live or dead chondrocytes cultured under standard conditions (B). $* * * \mathrm{P}<0.001, \mathrm{t}$ test. 


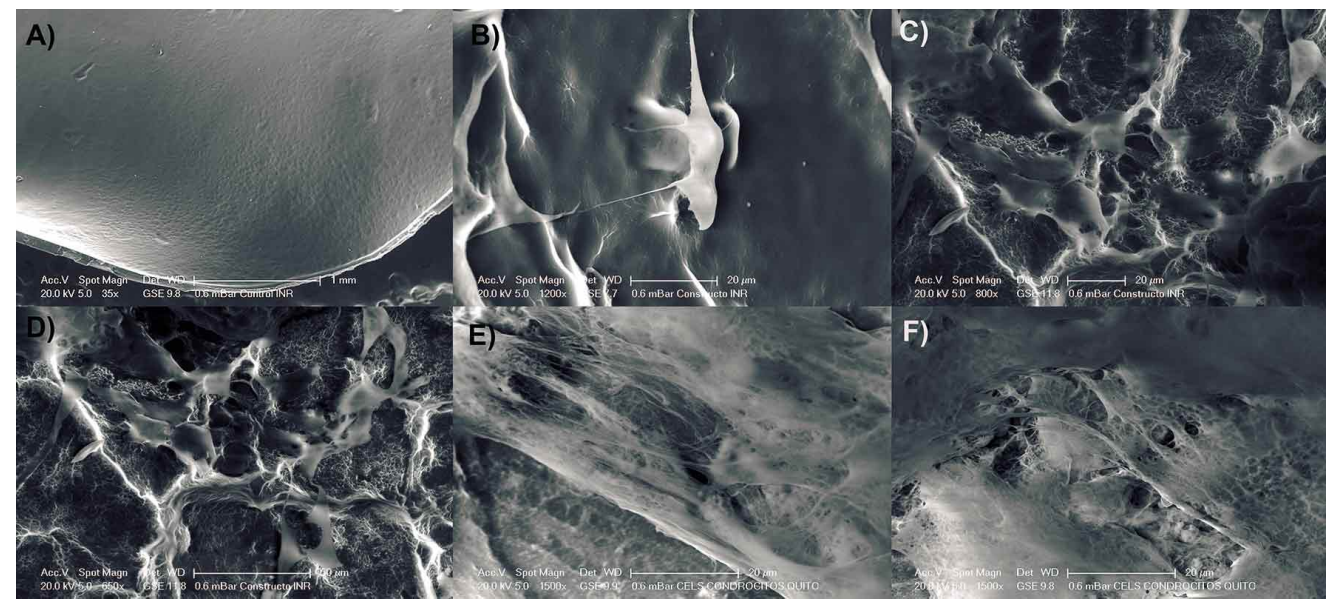

Fig. 4. Auricular chondrocytes attach and produce ECM onto CS-PVA-ECH hydrogels. SEM micrographs showed hydrogel surface and edges (A). Chondrocytes attached and displayed elongated morphology projecting filopodia (B). After 20 days culture, constructs produced abundant extracellular matrix $(\mathrm{C}-\mathrm{F})$ that was not observed in control hydrogel (A).

\section{CS-PVA-ECH hydrogel}

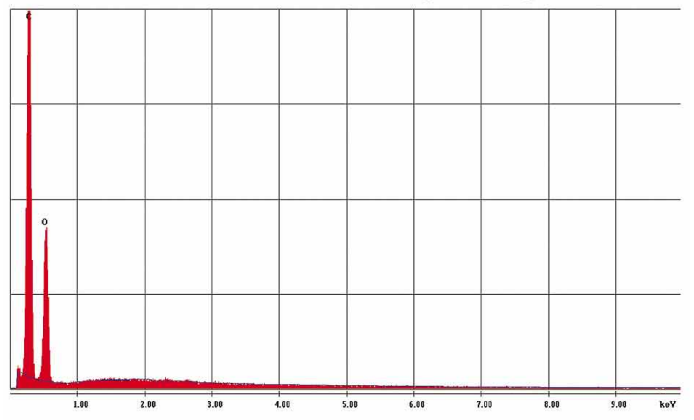

Auricular chondrocytes/ CS-PVA-ECH constructs

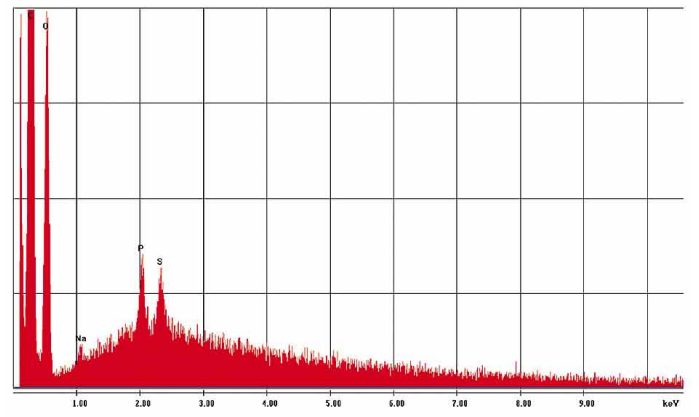

Fig. 5. Chemical characterization of CS-PVA-ECH hydrogels and constructs. Energy-dispersive X-ray spectrometry of CSPVA-ECH hydrogel (A) and auricular chondrocyte contructs (B) after 20 days culture. Traces of chlorine belonging to $\mathrm{ECH}$ decomposition were not detected in both conditions. Phosphorous and sulfur were present in constructs presumably integrating ECM (C). thickness varied between 50 to $80 \mu \mathrm{m}$ (Fig. 4A). Chondrocytes attached onto hydrogels are elongated, well spread, extend filopodia and secrete abundant extracellular matrix proteins (Fig. 4B-D). EDX analysis determined that the chemical elements that constituted the scaffold were carbon $73.24 \%$, oxygen $25.72 \%$ and sodium $1.04 \%$ for the control (Fig. 5A), while constructs containing auricular chondrocytes were constituted by carbon $76.30 \%$, oxygen $21.93 \%$, sodium $0.72 \%$, phosphorus $0.80 \%$ and sulfur $0.62 \%$. This analysis also demonstrates the absence of ECH traces in the hydrogel composition as previously demonstrated (Fig. 5B) (Nabzdyk).

Chondrocytes isolated from microtic cartilage maintain molecular phenotype during cell expansion and during growth onto hydrogel. To characterize chondrocyte phenotype, we analyzed whether microtic auricular chondrocytes changed gene expression through in vitro cell expansion as previously reported for normal chondrocytes. We were able to determine that mRNA levels for type II collagen and elastin, two of the main extracellular matrix components in elastic cartilage, persisted throughout in vitro expansion phase, from $\mathrm{T}$ to $\mathrm{PC}$ and $\mathrm{P} 1$; although levels of type II collagen diminished in these late two stages. Aggrecan expression levels remained constant during $\mathrm{PC}$ and $\mathrm{P} 1$. The transcriptional factor SOX9 was slightly expressed in chondrocytes readly isolated from surgical samples in all cases; however, after 3 weeks in primary culture they start to recover SOX9 expression and this recovery effect was evident after P1 finished. This phenomenon was observed separately in each sample. We also analyzed cartilage markers expression after cells were cultured for 20 days onto the CS-PVA-ECH hydrogel. It was noteworthy that 
MELGAREJO-RAMÍREZ, Y.; SÁNCHEZ-SÁNCHEZ, R.; GARCÍA-CARVAJAL, Z.; GARCÍA-LÓPEZ, J.; GUTIÉRREZ-GÓMEZ, C.; LUNA-BARCENAS, G.; IBARRA, C. \& VELASQUILLO, C. Biocompatibility of human auricular chondrocytes cultured onto a chitosan/polyvynil alcohol/epichlorohydrin-based hydrogel for tissue engineering application. Int. J. Morphol., 32(4):1347-1356, 2014

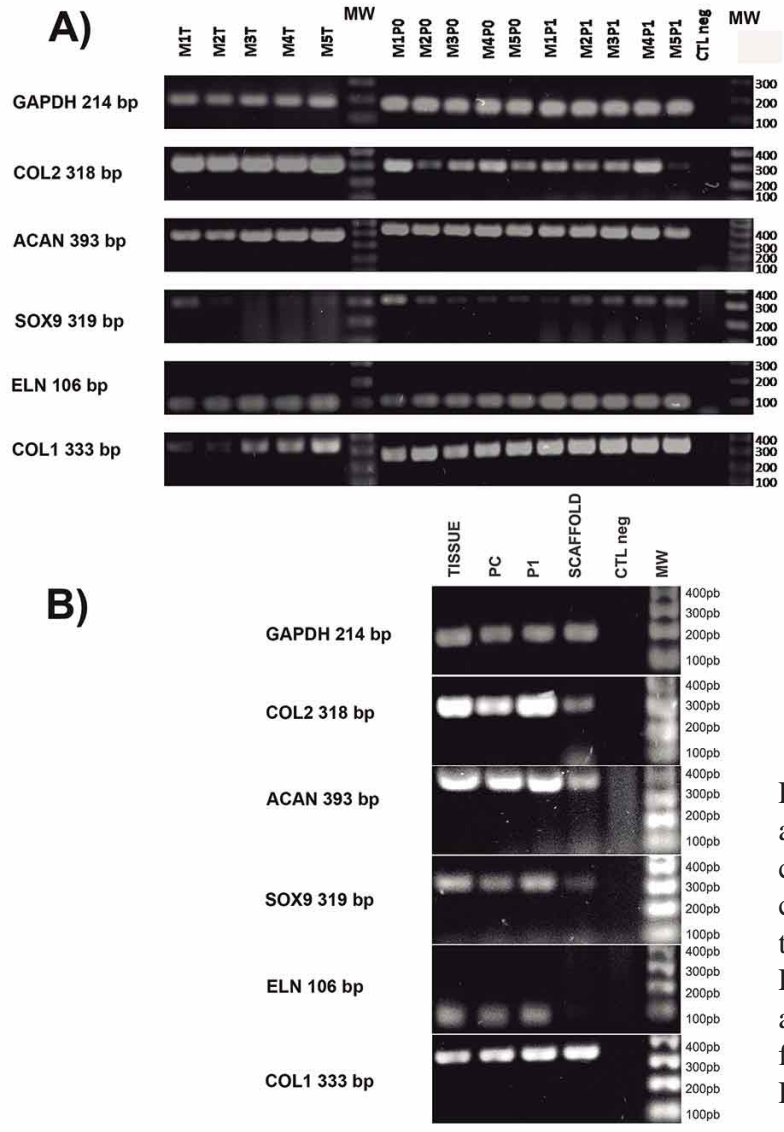

expression of COL2, ACAN and SOX9; even though diminished, was still detectable (Fig. 6). Remarkably, when cultured onto hydrogel for 20 days, SOX9 expression diminished but was not completely absent, suggesting that chondral phenotype was still present. We also detected expression of type I collagen in chondrocytes isolated from microtic tissue and in chondrocytes from PC and P1. Type I collagen expression slightly varied from tissue to in vitro culture among patients, remaining constant until culture concluded. After having analyzed molecular phenotype, our next goal was to evaluate the expression of these markers at protein level. In order to confirm the presence of elastic cartilage main extracellular matrix proteins in the constructs, immunohistochemical analysis was performed. We determined the presence of $98 \%$ positive cell for elastin (Fig. $7 \mathrm{~A}-\mathrm{C}$ ) and $97 \%$ positive cells for type II collagen (Fig. 7D-

Fig. 6. Molecular profile of auricular chondrocytes through cell expansion and cultured onto the CS-PVA-ECH hydrogel. Expression of type II collagen (COL II), Aggrecan (ACAN), SOX9, elastin (ELN) and type I collagen (COLI) was present in microtic auricular cartilage $(\mathrm{T})$, persisted through primary culture (PC), first passage (P1) as depicted in (A). Expression of cartilage markers was slightly diminished but still present after 20 days culture onto the scaffold (B). Analysis was performed in five independent samples (M1-5) and their respective stages (T, PC and P1). GAPDH expression was used as a loading control.
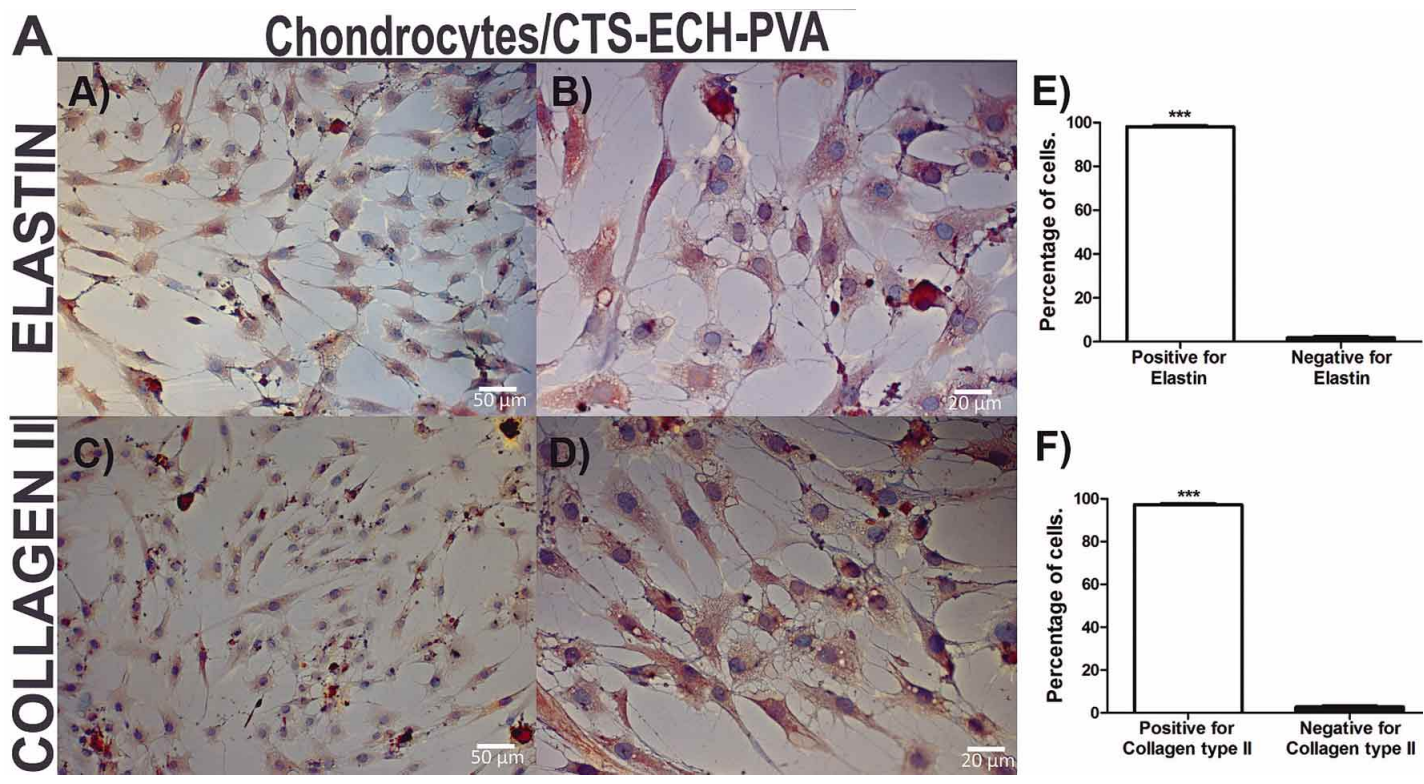

Fig. 7. Auricular chondrocytes expression of ECM proteins onto CS-PVA-ECH hydrogel. Chondrocytes cultured onto CS-PVA-ECH hydrogel showed positive reactivity for elastin (A and B) and for type II collagen (C and D). Nuclei were counterstained with hematoxylin dye (blue). Photographs were taken at different magnification. Graphs represent the percentage of positive cells to Elastin (E) or type II collagen $(\mathrm{F}) . * * * \mathrm{P}<0.001 \mathrm{t}$ test. 
F) when seeded onto CS-PVA-ECH hydrogels. These results revealed that although RNA levels were diminished, microtic chondrocytes expressed proteins such as type II collagen and elastin, constituting an extracellular matrix with similar composition to elastic cartilage when cultured in vitro conditions.

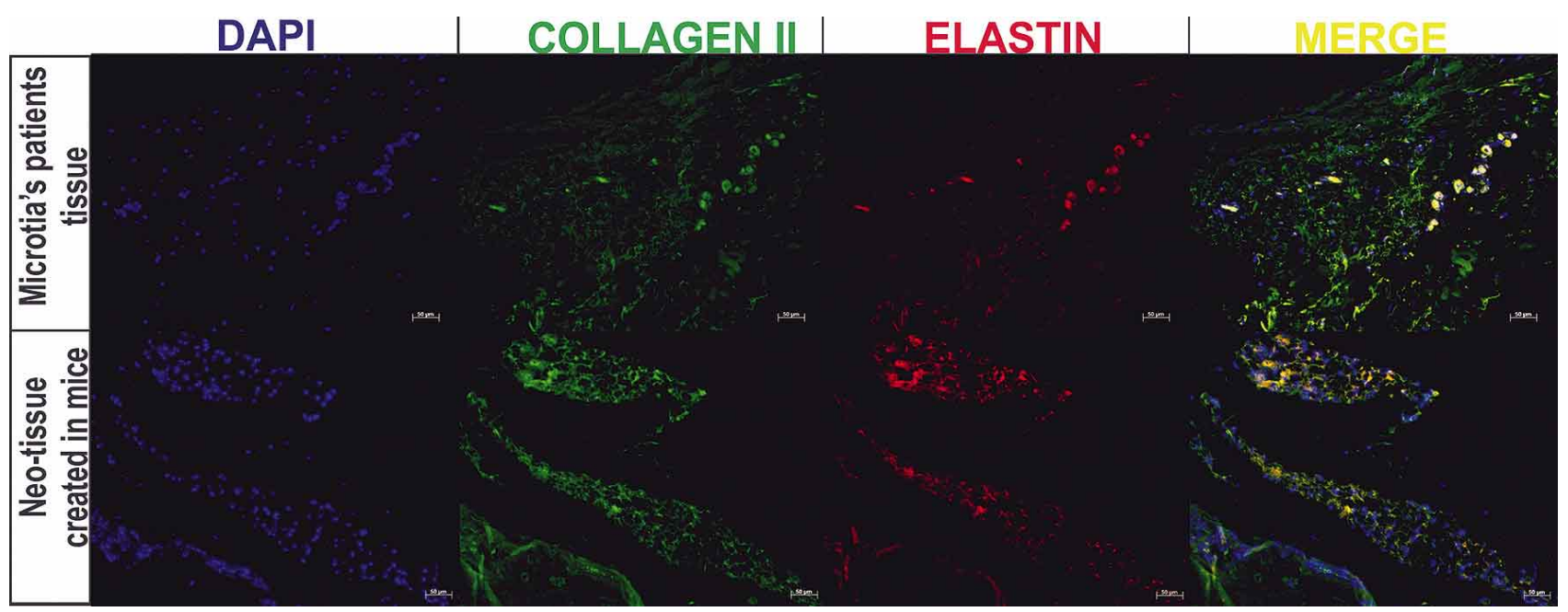

Fig. 8. Neotissues express elastic cartilage ECM proteins. Photographs show immunofluorescence for type II collagen (green) and elastin (red) in histological slices. Nuclei were stained with DAPI (blue) and co-localization is represented in yellow. Top images show microtic tissue from patients while bottom images represent tissue-engineered cartilage generated in nude mice after 4 months implantation.

Constructs induced in vivo neotissue formation. After viability was evaluated, constructs were implanted subcutaneously in athymic mice $(\mathrm{Nu} / \mathrm{Nu})$ for four months; mice were ethically sacrificed and neotissues were obtained. Neotissues had a yellowish coloration and were soft to the touch with little signs of vascularization around them. Hematoxylin/Eosin and Masson's stain revealed that cells and extracellular matrix constitute engineered tissue. Immunofluorescence analysis revealed that expression of type II collagen and elastin in neotissues is similar to protein expression in native cartilage from microtia patients (Fig. 8). This suggests that neotissue possesses similar composition to elastic cartilage and confirms that the CSPVA-ECH hydrogel is a suitable candidate for TE application.

\section{DISCUSSION}

The goal of tissue engineering is to repair, improve or replace damaged tissue in order to restore a lost function. Choosing the appropriate cell source and scaffold is crucial for successful tissue replacement (Park et al., 2002, 2004). We have previously performed the mechanical characterization and determination of the potential of the CS-PVA-ECH hydrogel for TE applications. We now analyzed the biocompatibility of human auricular chondrocytes isolated from cartilage remnants and cultured onto the CS-PVA-ECH hydrogel. As expected, we were able to expand chondrocytes from microtic cartilage, these cells displayed similar morphology and regular growth when compared with normal chondrocytes previously reported (Yamaoka et al., 2006; Yanaga et al., 2012).

Cell viability is an important parameter to determine biocompatibility and whether it damages the cells required for neotissue formation. In this study, chondrocytes viability was higher than $81 \%$ confirming hydrogel biocompatibility. Formation of an ECM directs cell fate like survival, proliferation or differentiation mediated by the binding of ECM to membrane components in cells (Schlie-Wolter et al., 2000). As shown, auricular chondrocytes cultured onto CS-PVA-ECH hydrogel were capable to secrete ECM once attached to the surface and this protein adsorption to the hydrogel is important for the integration of the biomaterial once it is introduced into an organism. Previous studies have shown that chondrocytes change their phenotype during monolayer culture based on the expression of cartilage molecular markers such as type II collagen and the transcriptional factor SOX9 (Murakami et al., 2000). However, we observed that expression of these molecular markers in microtic chondrocytes persisted through in vitro expansion and after constructs were assembled. Interestingly, after 20 days culture onto CS-PVA-ECH hydrogel, chondrocytes maintained SOX9 expression in a lesser extent than monolayer culture, indicating that they still retain auricular chondrocyte phenotype. SOX9 is essential for phenotype maintenance and it is expressed in regions where deposition of cartilage matrix takes place, promoting 
MELGAREJO-RAMÍREZ, Y.; SÁNCHEZ-SÁNCHEZ, R.; GARCÍA-CARVAJAL, Z.; GARCÍA-LÓPEZ, J.; GUTIÉRREZ-GÓMEZ, C.; LUNA-BARCENAS, G.; IBARRA, C. \& VELASQUILLO, C. Biocompatibility of human auricular chondrocytes cultured onto a chitosan/polyvynil alcohol/epichlorohydrin-based hydrogel for tissue engineering application. Int. J. Morphol., 32(4):1347-1356, 2014

expression of type II collagen and aggrecan (Sekiya et al., 2001; Patel et al., 2000). Elastic cartilage is conformed predominantly by elastic fibers and type II collagen; however, a small expression of type I collagen is reported to be around 5\% (Eyre \& Muir, 1975).

It has been widely described that type I collagen expression is an indicative of chondrocyte dedifferentiation; however, this phenomena has been observed in chondrocytes isolated from articular cartilage. Unlike articular cartilage, elastic cartilage is surrounded by perichondrium which is conformed by an outer layer containing fribroblasts and an inner layer containing undifferentiated chondrocytes. It has been recently reported that perichondrium contains a population of cartilage progenitor cells with potential to differentiate into mature chondrocytes (Togo et al., 2006). With this in mind, microtic tissue was carefully dissected leaving a small portion of perichondrium to include and isolate a fraction of the aforementioned progenitor cells. Thus, levels of expression of type I collagen might belong either to the small fraction expressed in chondrocytes or to those fibroblasts that are part of perichondrium; and not necessarily due to a dedifferentiation process. More experiments should be performed in order to confirm this hypothesis. Elastin is the protein that confers elasticity to elastic cartilage, preventing tissue creeping by stretching under load and recoiling to their original configurations after the load is released (Kusuhara et al., 2009). Immunohistochemical assay showed that an elevated number of auricular chondrocytes from microtia cultured onto CS-PVA-ECH hydrogel were still able to express elastin and type II collagen in concordance with mRNA analysis. This effect confirms the abundant ECM formation revealed by SEM analysis. Finally, our in vivo assay of tissue formation showed that after 4 months implantation in athymic mice; constructs generated neotissues with similar physical characteristics and protein composition (elastin and type II collagen) similar to those found in elastic cartilage.

\section{CONCLUSIONS}

Tissue engineering dictates that cell-scaffold interactions are vital to provide an adequate integrity of the ECM and consolidation of a tissue. As demonstrated in this study, the CS-PVA-ECH hydrogel is biocompatible and represents a good alternative to support viability, cell growth and extracellular matrix deposition of auricular chondrocytes. We confirmed the biocompatibility of the CSPVA-ECH hydrogel using human microtic auricular chondrocytes and propose the use of this hydrogel as a promising alternative scaffold for tissue engineering applications.

\section{ACKNOWLEDGEMENTS}

Support for this research was provided through CONACYT grants (Sectoriales 114359 and 78798). The authors would like to thank Dr. Hugo Lecona for his support on animal handling and surgery; M. Sc. Lilia Solís for her technical support on SEM analysis; Karina Martínez and Xochitl Guerrero for her technical support.

MELGAREJO-RAMÍREZ, Y.; SÁNCHEZ-SÁNCHEZ, R.; GARCÍA-CARVAJAL, Z.; GARCÍA-LÓPEZ, J.; GUTIÉRREZ-GÓMEZ, C.; LUNA-BARCENAS, G.; IBARRA, C. \& VELASQUILLO, C. Biocompatibilidad de condrocitos humanos cultivados sobre un hidrogel a base de quitosano/alcohol polivinílico/epiclorhidrina para aplicación en ingeniería de tejidos. Int. J. Morphol., 32(4):13471356, 2014.

RESUMEN: La ingeniería de tejidos (TE) es una alternativa para la reconstrucción auricular basada en la combinación de células, señales moleculares y biomateriales. Los andamios fabricados con biomateriales brindan un soporte estructural que favorece la adhesión cellular y el desarrollo del tejido. Un andamio debe poseer características como biocompatibilidad y bioactividad para soportar adecuadamente funciones celulares. Nuestro objetivo fue evaluar la biocompatibilidad de condrocitos auriculares de microtia cultivados sobre un hidrogel a base de quitosanoalcohol polivinílico-epiclorhidrina (CS-PVA-ECH) y proponerlo como andamio con aplicaciones en ingeniería de tejidos. La viabilidad de los condrocitos auriculares es superior al $81 \%$ después de ser cultivados sobre el hidrogel. El análisis por SEM reveló la unión celular y formación de matriz extracellular sobre el hidrogel; confirmada mediante detección por IF de colágena tipo II y elastina. La expresión de marcadores moleculares durante la expansión in vitro y el cultivo sobre los hidrogeles confirmaron el fenotipo condral. El ensayo de formación de tejido in vivo demostró la generación de neotejidos con características físicas y composición similar al cartílago elástico. Nuestros resultados indican que la biocompatibilidad del hidrogel de CS-PVA-ECH lo hace un andamio adecuado para aplicaciones en ingeniería de tejidos enfocadas a regeneración de cartílago elástico.

PALABRAS CLAVE: Cartílago elástico; Reconstrucción auricular; Hidrogel quitosano; Ingeniería de tejidos; Biocompatibilidad.

\section{REFERENCES}

Akiyama, H.; Chaboissier, M. C.; Martin, J. F.; Schedl, A. \& de Crombrugghe, B. The transcription factor Sox 9 has essential roles in successive steps of the chondrocyte differentiation pathway and is required for expression of Sox 5 and Sox6. Genes Dev., 16(21):2813-28, 2002. 
MELGAREJO-RAMÍREZ, Y.; SÁNCHEZ-SÁNCHEZ, R.; GARCÍA-CARVAJAL, Z.; GARCÍA-LÓPEZ, J.; GUTIÉRREZ-GÓMEZ, C.; LUNA-BARCENAS, G.; IBARRA, C. \&

VELASQUILLO, C. Biocompatibility of human auricular chondrocytes cultured onto a chitosan/polyvynil alcohol/epichlorohydrin-based hydrogel for tissue engineering application. Int. J. Morphol., 32(4):1347-1356, 2014.

Di Martino, A.; Sittinger, M. \& Risbud, M. V. Chitosan: a versatile biopolymer for orthopaedic tissue-engineering. Biomaterials, 26(30):5983-90, 2005.

Dorj, B.; Won, J. E.; Kim, J. H.; Choi, S. J.; Shin, U. S. \& Kim, H. W. Robocasting nanocomposite scaffolds of poly(caprolactone)/ hydroxyapatite incorporating modified carbon nanotubes for hard tissue reconstruction. J. Biomed. Mater. Res. A, 101(6):1670-81, 2013.

Eyre, D. R. \& Muir, H. The distribution of different molecular species of collagen in fibrous, elastic and hyaline cartilages of the pig. Biochem. J., 151(3):595-602, 1975.

Gao, W.; Lai, J. C.; \& Leung, S. W. Functional enhancement of chitosan and nanoparticles in cell culture, tissue engineering, and pharmaceutical applications. Front. Physiol., 3:321, 2012.

Garnica-Palafox, I. M.; Sánchez-Arévalo, F. M.; Velasquillo, C.; GarcíaCarvajal, Z. Y.; García-López, J.; Ortega-Sánchez, C.; Ibarra, C.; LunaBárcenas, G. \& Solís-Arrieta, L. Mechanical and structural response of a hybrid hydrogel based on chitosan and poly (vinyl alcohol) crosslinked with epichlorohydrin for potential use in tissue engineering. $J$. Biomater. Sci. Polym. Ed., 25(1):32-50, 2014.

Hutmacher, D. W.; Goh, J. C. \& Teoh, S. H. An introduction to biodegradable materials for tissue engineering applications. Ann. Acad. Med. Singapore, 30(2):183-91, 2001.

Kobayashi, S.; Takebe, T.; Inui, M.; Iwai, S.; Kan, H.; Zheng, Y. W.; Maegawa, J. \& Taniguchi, H. Reconstruction of human elastic cartilage by a CD44+ CD90+ stem cell in the ear perichondrium. Proc. Natl. Acad. Sci. USA, 108(35):14479-84, 2011.

Kusuhara, H.; Isogai, N.; Enjo, M.; Otani, H.; Ikada, Y.; Jacquet, R.; Lowder, E. \& Landis, W. J. Tissue engineering a model for the human ear: assessment of size, shape, morphology, and gene expression following seeding of different chondrocytes. Wound Repair Regen., 17(1):13646, 2009.

Lafont, J. E.; Talma, S.; Hopfgarten, C. \& Murphy, C. L. Hypoxia promotes the differentiated human articular chondrocyte phenotype through SOX9-dependent and -independent pathways. J. Biol. Chem., 283(8):4778-86, 2008.

Lee, S. H. \& Shin, H. Matrices and scaffolds for delivery of bioactive molecules in bone and cartilage tissue engineering. Adv. Drug Deliv. Rev., 59(4-5):339-59, 2007.

Luquetti, D. V.; Heike, C. L.; Hing, A. V.; Cunningham, M. L. \& Cox, T. C. Microtia: epidemiology and genetics. Am. J. Med. Genet. A, 158A(1):124-39, 2012.

Murakami, S.; Kan, M.; McKeehan, W. L. \& de Crombrugghe, B. Upregulation of the chondrogenic Sox 9 gene by fibroblast growth factors is mediated by the mitogen-activated protein kinase pathway. Proc. Natl. Acad. Sci. USA, 97(3):1113-8, 2000.

Nabzdyk, C.; Pradhan, L.; Molina, J.; Perin, E.; Paniagua, D. \& Rosenstrauch, D. Review: auricular chondrocytes - from benchwork to clinical applications. In Vivo, 23(3):369-80, 2009.

Park, S. S.; Chi, D. H.; Lee, A. S.; Taylor, S. R. \& Iezzoni, J. C. Biomechanical properties of tissue-engineered cartilage from human and rabbit chondrocytes. Otolaryngol. Head Neck Surg., 126(1):527, 2002.

Park, S. S.; Jin, H. R.; Chi, D. H. \& Taylor, R. S. Characteristics of tissueengineered cartilage from human auricular chondrocytes. Biomaterials, 25(12):2363-9, 2004.

Patel, A.; Fine, B.; Sandig, M. \& Mequanint, K. Elastin biosynthesis: The missing link in tissue-engineered blood vessels. Cardiovasc. Res., 71(1):40-9, 2006.

Ruszymah, B. H.; Lokman, B. S.; Asma, A.; Munirah, S.; Chua, K.; Mazlyzam, A. L.; Isa, M. R.; Fuzina, N. H. \& Aminuddin, B. S. Pediatric auricular chondrocytes gene expression analysis in monolayer culture and engineered elastic cartilage. Int. J. Pediatr. Otorhinolaryngol., 71(8):1225-34, 2007.

Schlie-Wolter, S.; Ngezahayo, A. \& Chichkov, B. N. The selective role of ECM components on cell adhesion, morphology, proliferation and communication in vitro. Exp. Cell Res., 319(10):1553-61, 2013.

Sekiya, I.; Koopman, P.; Tsuji, K.; Mertin, S.; Harley, V.; Yamada, Y.; Shinomiya, K.; Nifuji, A. \& Noda, M. Dexamethasone enhances SOX9 expression in chondrocytes. J. Endocrinol., 169(3):573-9, 2001.

Togo, T.; Utani, A.; Naitoh, M.; Ohta, M.; Tsuji, Y.; Morikawa, N.; Nakamura, M. \& Suzuki, S. Identification of cartilage progenitor cells in the adult ear perichondrium: utilization for cartilage reconstruction. Lab. Invest., 86(5):445-57, 2006.

Vinatier, C.; Mrugala, D.; Jorgensen, C.; Guicheux, J. \& Noël, D. Cartilage engineering: a crucial combination of cells, biomaterials and biofactors. Trends Biotechnol., 27(5):307-14, 2009.

Yamaoka, H.; Asato, H.; Ogasawara, T.; Nishizawa, S.; Takahashi, T.; Nakatsuka, T.; Koshima, I.; Nakamura, K.; Kawaguchi, H.; Chung, U. I.; Takato, T. \& Hoshi, K. Cartilage tissue engineering using human auricular chondrocytes embedded in different hydrogel materials. $J$. Biomed. Mater. Res. A, 78(1):1-11, 2006.

Yanaga, H.; Imai, K.; Koga, M. \& Yanaga, K. Cell-engineered human elastic chondrocytes regenerate natural scaffold in vitro and neocartilage with neoperichondrium in the human body post-transplantation. Tissue Eng. Part A, 18(19-20):2020-9, 2012.

Zhang, Y. \& Zhang, M. Synthesis and characterization of macroporous chitosan/calcium phosphate composite scaffolds for tissue engineering. J. Biomed. Mater. Res., 55(3):304-12, 2001.

Correspondence to:

Cristina Velasquillo

Laboratorio de Biotecnología

Instituto Nacional de Rehabilitación

México Distrito Federal

C.P.14389

MÉXICO

Email: mvelasquillo@inr.gob.mx

Received: 02-09-2014

Accepted: 22-09-2014 